\title{
The Effect of Agrobost Biofertilizer on the Growth and Productivity of Potato (Solanum tuberosum) Variety Granola L
}

\author{
Pengaruh Pupuk Hayati Agrobost Terhadap Pertumbuhan dan \\ Produktivitas Kentang (Solanum tuberosum) Varietas Granola L
}

\author{
Nira Hadayanti \\ \{nhadayanti2@gmail.com\}
}

Program Studi Biologi, Fakultas Sains dan Teknologi, UIN Sunan Gunung Djati Bandung

\begin{abstract}
Potato is a staple food substitute that has a high consumption value. Potato productivity in Indonesia is still inadequate, especially for high-quality seeds. Agrobost is a biological fertilizer that contains microorganisms that can help provide nutrients for plants and can increase the productivity of potato plants. This study aims to determine the effect and optimum dose of agrobost biofertilizer on the growth and productivity of potato (Solanum tuberosum) Granola L variety. The research design used was a non-factorial randomized block design (RAK) with 6 levels of dose treatment and 4 repetitions. The doses used were $0 \mathrm{ml}$ (d0/control), $5 \mathrm{ml}$ (d1), $10 \mathrm{ml}$ (d2), $15 \mathrm{ml}(\mathrm{d} 3$ ), $20 \mathrm{ml}(\mathrm{d} 4)$, and $25 \mathrm{ml}(\mathrm{d5})$. Parameters observed were plant height, number of leaves, plant wet weight, plant dry weight, total number of tubers, and total weight of tubers. The data obtained quantitatively were analyzed using analysis of variance (ANOVA) followed by a 5\% honest real difference test (BNJ). It was found that the application of Agrobost biofertilizer had a significant effect on the weight of potato tubers but had no significant effect on plant height, number of leaves, fresh weight and dry weight of plants and the number of potato tubers. Agrobost biofertilizer with a dose of $20 \mathrm{ml} / \mathrm{L}$ produced the highest average tuber weight, which was 7.71 grams.
\end{abstract}

Keywords - Agrobost; Granola; Growth; Productivity; Tubers

\begin{abstract}
Abstrak. Kentang merupakan bahan pengganti makanan pokok yang memiliki nilai konsumsi tinggi. Produktivitas kentang di Indonesia masih kurang memadai, khususnya untuk benih yang berkualitas tinggi. Agrobost merupakan pupuk hayati yang mengandung mikroorganisme yang dapat membantu menyediakan hara untuk tanaman dan dapat meningkatkan produktivitas tanaman kentang. Penelitian ini bertujuan untuk mengetahui pengaruh dan dosis pupuk hayati agrobost yang optimum pada pertumbuhan dan produktivitas kentang (Solanum tuberosum) varietas Granola L. Rancangan penelitian yang digunakan yaitu Rancangan Acak Kelompok (RAK) non faktorial dengan 6 taraf perlakuan dosis dan 4 kali pengulangan. osis yan digunakan yaitu $0 \mathrm{ml}$ (d0/Kontrol), $5 \mathrm{ml}$ (dl), $10 \mathrm{ml}(d 2), 15$ $\mathrm{ml}$ (3), $20 \mathrm{ml}$ (d4), dan $25 \mathrm{ml}$ (d5). Parameter yang diamati yaitu tinggi tanaman, jumlah daun, bobot basah tanaman bobot kering tanaman, jumlah total umbi, dan bobot total umbi. Data yang diperoleh secara kuantitatif dilakukan analisis dengan analysis of Variance (ANOVA) dilanjutkan dengan uji beda nyata jujur (BNJ) tingkat 5\%. Didapatkan hasil bahwa pemberian pupuk hayati Agrobost berpengaruh nyata terhadap bobot umbi kentang tetapi tidak perpengaruh nyata terhadap tinggi tanaman, jumlah daun, bobot segar dan bobot kering tanaman serta jumlah umbi kentang. Pupuk hayati Agrobost dengan dosis $20 \mathrm{ml} / \mathrm{L}$ menghasilkan rerata bobot umbi tertingi yaitu seberat 7.71 gram.
\end{abstract}

Kata Kunci-Agrobost; Granola; Pertumbuhan; Produktivitas; Umbi

\section{PENDAHULUAN}

Kentang (Solanum tuberosum) merupakan tanaman yang masuk dalam komoditi hortikultura. Kentang memiliki nilai konsumsi yang sangat besar karena vitamin yang dikandungnya serta kentang juga dapat dijadikan sebagai pengganti makanan pokok dan juga berbagai macam olahan. Kentang memiliki kandungan gizi diantaranya yaitu karbohidrat, zat besi, kalium, kalsium, natrium, protein dan vitamin. Selain itu, kentang juga mengandung ju,lah lemak yang relatif sedikit yaitu $1.0-1.5 \%$ [1]. Produksi kentang sejak tahun 2016 hingga tahun 2017 mengalami penurunan sebesar 3,9\%. Hal ini terkait dengan penggunan benih berkualitas rendah, penyediaan dan distribusi benih kentang berkualitas tinggi yang tidak berkesinambungan dan memadai [2].

Penyediaan kentang di Indonesia masih kurang memadai, khususnya untuk benih yang berkualitas tinggi serta bebas hama dan penyakit. Walaupun di Indonesia tanaman kentang telah banyak dibudidayakan, namun nilai ratarata produksinya rendah. Rendahnya produksi kentang di Indonesia disebabkan karena mutu benih yang digunakan bukan benih bersertifikat serta sulitnya mendapatkan benih berkualitas tinggi di pasaran [3]. Selain itu juga terdapat kendala yang bersifat teknis maupun nonteknis seperti kualitas kesuburan tanah yang menurun, kurangnya 
pengelolaan atau konversi tanah serta frekuensi penggunaan pupuk kimia yang berlebihan dan kontinyu selama musim tanam [4].

Tanaman kentang akan tumbuh dan berkembang pada iklim yang ideal yaitu pada kisaran suhu $15^{\circ}-20^{\circ} \mathrm{C}$. Untuk pembentukan umbi normal dibutuhkan suhu tanah berkisar antara $15^{\circ}-18^{\circ} \mathrm{C}$ [5]. Namun begitu, tanaman kentang masih dapat tumbuh baik pada suhu minimum $15^{\circ} \mathrm{C}$ dan maksimum yaitu $30^{\circ} \mathrm{C}$. Kelembaban udara yang dibutuhkan oleh tanaman kentang yaitu sebanyak 80 - 90\% dengan penyinaran matahari penuh sekitar 10 hinga 16 jam selama pertumbuhan. Di Indonesia, dengan ketinggian 500 - 3000 mdpl tanaman kentang dapat diusahakan untuk tumbuh, namun pada ketinggian antara 1000 - 2000 mdpl merupakan ketinggian terbaik untuk kentang dapat tumbuh dan berkembang. Tanah yang cocok untuk pertumbuhan tanaman kentang yaitu bersifat subur dan gembur, dengan bahan organik yang berlimpah, $\mathrm{pH}$ tanah berkisar antara 5 hingga 6.5, bersolum dalam, serta drainase dan aerasi yang baik [6].

Pengunaan pupuk hayati merupakan salah satu upaya agar nilai produktivitas kentang dapat meningkat. Pupuk hayati atau biofertilizer adalah pupuk yang terdiri dari mikroorganisme yang dapat membantu tanaman untuk menyediakan dan meningkatkan penyerapan unsur hara. Mikroba dalam pupuk hayati membantu tanaman untuk menyerap unsur hara yang sulit diserap tanaman. Pengunaan pupuk hayati akan membantu proses biologis sehingga ketersediaan hara meningkat dan dapat dimanfaatkan oleh tanaman. Agrobost merupakan salah satu pupuk hayati yang memiliki komposisi mikroorganisme baik yang membantu menyediakan nutrisi untuk pertumbuhan dan perkembangan tanaman. Telah banyak penelitian membuktikan bahwa pupuk hayati agrobost memiliki pengaruh nyata terhadap produktivitas tanaman. Konsentrasi pupuk hayati Agrobost dengan konsentrasi 15cc/L air mendapatkan hasil baik pada pertumbuhan tinggi tanaman, dan diameter buah tanaman tomat [7]. Agrobost juga berpengaruh sangat nyata terhadap tinggi tanaman, jumlah cabang produktif, umur berbunga, berat buah cabe rawit [8].

Penggunaan pupuk hayati juga dapat bersifat ramah lingkungan karena mengurangi penggunaan pupuk kimia dan efek buruk terhadap kesehatan tanaman. Pupuk hayati juga dapat memperbaiki struktur, tekstur dan daya ikat air oleh tanah. Pupuk hayati juga memberikan pengaruh yang sangat baik terhadap pertumbuhan dan hasil produksi tanaman tomat [9].

Saat ini belum adanya penelitian tentang pengaruh pupuk hayati agrobost terhadap pertumbuhan dan produktivitas kentang, maka dari itu penelitian ini penting dilakukan untuk mengetahui pengaruh serta dosis pupuk hayati agrobost yang optimum untuk pertumbuhan dan produktivitas tanaman kentang (Solanum tuberosum) varietas Granola L.

\section{METODE}

\section{A. Rancangan penelitian}

Penelitian dilakukan di Unit Screen House A nomor 07 UPTD Balai Benih Kentang Pangalengan pada bulan Maret - Juni 2021. Varietas kentang yang digunakan yaitu varietas granola. Pupuk hayati yang digunakan yaitu pupuk hayati Agrobost. Rancangan penelitian yang digunakan yaitu Rancangan Acak Kelompok (RAK) non faktorial dengan 6 taraf perlakuan dosis dan 4 kali ulangan. Dosis yan digunakan yaitu $0 \mathrm{ml}(\mathrm{d} 0 / \mathrm{Kontrol}), 5 \mathrm{ml}(\mathrm{d} 1)$, $10 \mathrm{ml}$ (d2), $15 \mathrm{ml}$ (3), $20 \mathrm{ml}$ (d4), dan $25 \mathrm{ml}$ (d5). Maka diperoleh kombinasi perlakuan yaitu sebanyak 24 unit percobaan. Jumlah umbi mikro yang digunakan sebanyak 240 umbi dengan masing - masing perlakuan sebanyak 10 umbi. Dan masing - masing polybag diisi dengan 1 umbi.

\section{B. Langkah penelitian}

Persiapan tanam

Persiapan tanam meliputi sterilisasi screen house dan persiapan media tanam. Tempat yang akan ditanami kentang disterilisasi terlebih dahulu dengan cara menyemprotkan larutan pestisida pada seluruh bagian ruangan Screen House A. Bahan dasar yang digunakan untuk media tanam yaitu cocopeat dan pupuk organik (kotoran ayam) dengan perbandingan 3:1. Media tanam disterilisasi menggunakan alat steam boiler lalu dimasukan kedalam polybag ukuran $15 \times 30$.

\section{Penanaman}

Umbi yang digunakan adalah umbi yang telah siap tanam. Dibuat lubang tanam sedalam $\pm 5 \mathrm{~cm}$ lalu umbi dimasukan dan ditutup kembali dengan media tanam. Kemudian dilakukan penyiraman secukupnya $( \pm 1$ liter / polybag) sesuai kapasitas lapang guna menghindari terjadi kebusukan akibat terlalu banyak air.

\section{Pemupukan}

Pemupukan dilakukan sebanyak 3 kali, pertama saat sebelum tanam, pupuk selanjutnya diberikan pada 30 hari setelah tanam (HST) dan 60 HST. Dengan dosis yang telah ditentukan yaitu $5 \mathrm{ml} / \mathrm{L}, 10 \mathrm{ml} / \mathrm{L}, 15 \mathrm{ml} / \mathrm{L}, 20 \mathrm{ml} / \mathrm{L}$, dan $25 \mathrm{ml} / \mathrm{L}$. 
Pemeliharaan tanaman

Pemeliharaan tanaman kentang terdiri dari penyiraman, rouging, pemasangan ajir dan pengendalian hama penyakit. Penyiraman dilakukan 1 - 2 kali dalam satu minggu (disesuaikan dengan situasi dan kondisi tanaman). Rouging dilakukan dengan cara membuang tanaman yang tidak dikehendaki. Dan Pengendalian hama dan penyakit dilakukan dengan memadukan pengendalian secara kimiawi dengan menggunakan pestisida dan non kimiawi menggunakan yellow trap.

\section{Pra-panen}

Sebelum dilakukan panen, terlebih dahulu dilakukan panen sampel. Pada saat tanaman berumur 75 - 80 HST. Panen sampel dimaksudkan untuk mengetahui keadaan umbi, ukuran, prediksi produksi dan penentuan waktu panen dan pangkas batang. Pangkas batang dilakukan $7-10$ hari sebelum panen atau $80-90$ HST, dengan maksud untuk menguatkan kulit umbi, mempertahankan ukuran umbi, mencegah penularan hama dan penyakit dari bagian atas tanaman ke umbi serta memudahkan pada saat panen [10].

\section{Panen}

Panen dilaksanakan 7 - 10 hari setelah pangkas batang atau pada saat usia tanaman $\pm 90-100$ HST, tepatnya pada saat tanaman berusia 93 HST dengan terlebih dahulu menggemburkan media tanam guna menghindari terjadinya kerusakan fisik pada umbi.

\section{Pengamatan}

Pengamatan terdiri dari pengamatan penunjang dan pengamatan utama Pengamatan penunjang merupakan pengamatan yang datanya tidak dianalisis secara statistik. Komponen pengamatan yang diamati yaitu Analisis kimia kandungan media tanam yang diuji di Laboratorium Balai penelitian Tanaman Sayuran (BALITSA), pengukuran suhu udara dan kelembaban udara dengan menggunakan hygrometer, pengukuran $\mathrm{pH}$ dan kelembaban tanah dengan menggunakan soil tester. Sedangkan pengamatan utama terdiri dari:

1. Tinggi tanaman. Pengukuran dilakukan dengan cara mengukur tinggi tanaman yang dimulai dari permukaan tanah sampai titik tumbuh tanaman [11]. Pengamatan dilakukan pada saat tanaman berumur 30, 40, 50, dan 60 HST dengan interval pengukuran 10 hari setelah tanaman berumur 30 HST.

2. Jumlah Daun. Jumlah daun dihitung secara manual. Daun dihitung yaitu daun yang telah membuka sempurna. Tiap helai daun dihitung kecuali daun yang masih kuncup [12]. Pengukuran dilakukan pada saat tanaman berumur 30, 40, 50, dan 60 HST dengan interval pengukuran 10 hari setelah tanaman berumur 30 HST.

3. Berangkasan tanaman Pengamatan berangkasan tanaman meliputi bobot berangkasan segar dan bobot berangksan kering tanaman. Pengamatan bobot berangkasan segar tanaman dilakukan dengan menimbang keseluruhan tanaman sampel (kecuali umbi) dengan menggunakan timbangan digital pada saat pemanenan yaitu sekitar tanaman berumur 87 hari setelah tanam.Pengamatan bobot berangkasan kering dilakukan setelah tanaman dioven dengan suhu $80^{\circ} \mathrm{C}$ sampai mencapai bobot kering konstan. Bagian tanaman yang diukur berupa keseluruhan bagian tanaman kecuali bagian umbi. Setelah pengovenan selanjutnya ditimbang dengan menggunakan timbangan digital [13].

4. Jumlah Umbi. Penghitungan jumlah umbi dilakukan setelah panen dengan menghitung jumlah umbi pada setiap tanaman.

5. Bobot umbi. Penghitungan bobot umbi dilakukan setelah panen dengan menimbang berat umbi pertanaman dengan timbangan digital dan mengkategorikannya berdasarkan berat tersebut.

Analisis data yang digunakan pada penelitian ini yaitu analisis statistik dengan DSAASTAT. Data yang diperoleh secara kuantitatif dilakukan analisis dengan analysis of Variance (ANOVA). Apabila data hasil uji ANOVA berbeda secara nyata maka dilanjutkan dengan uji beda nyata jujur (BNJ) atau Tukey HSD pada tingkat $5 \%$.

\section{HASIL DAN PEMBAHASAN}

\section{A. Pengamatan penunjang}

Analisis kandungan media tanam

Hasil analisis media tanam yang dilakukan di Laboratorium Balai Penelitian Tanaman dan Sayuran disajikan dalam tabel berikut: 
Procedia of Engineering and Life Science Vol. 2 No. 1 October 2021

Seminar Nasional \& Call Paper Fakultas Sains dan Teknologi (SENASAINS 3 ${ }^{\text {rd) }}$

Universitas Muhammadiyah Sidoarjo

Tabel 1. Hasil Analisis Kimia Fisika tanah sebelum diberi perlakuan

\begin{tabular}{lcl}
\hline \multicolumn{1}{c}{ Sifat Tanah } & Hasil Analisis & Kriteria $(*)$ \\
\hline Tekstur & & \\
Pasir (\%) & 4 & Lempung berdebu \\
Debu (\%) & 74 & \\
Liat (\%) & 22 & Netral \\
$\mathrm{pH} \mathrm{H} \mathrm{H}_{2} \mathrm{O}$ & 6.8 & Sangat Tinggi \\
$\mathrm{C}-$ Organik $(\%)$ & 46.35 & Sangat Tinggi \\
N-Total $(\%)$ & 1.3 & Sangat Tinggi \\
Rasio C/N & 36 & Sangat Tinggi \\
P total $(\mathrm{mg} / 100 \mathrm{~g})$ & 122.19 & Sangat Tinggi \\
P tersedia $(\mathrm{ppm})$ & 125.6 & Sangat Tinggi \\
K total $(\mathrm{mg} / 100 \mathrm{~g})$ & 377.31 & Sangat Tinggi \\
K tersedia $(\mathrm{ppm})$ & 5157 & Sangat Tinggi \\
KTK $(\mathrm{cmol} / \mathrm{kg})$ & 65.89 & \\
\hline
\end{tabular}

Keterangan (*) : Pemberian kriteria berdasarkan penilaian analisis kimia tanah Balai Penelitian Tanah (2005)

Tekstur media tanam yang digunakan pada penelitian ini yaitu termasuk kedalam lempung berdebu. Kemasaman media termasuk netral dengan $\mathrm{pH} \mathrm{H}_{2} \mathrm{O}$ sebesar 4.8. Kandungan unsur hara makro termasuk kedalam kategori sangat tinggi. Begitu juga nilai bahan organik, rasio $\mathrm{C} / \mathrm{N}$, serta KTK.

\section{B. Pengamatan utama}

Tinggi tanaman

Berdasarkan hasil analysis of variance (ANOVA) pemberian pupuk hayati agrobost tidak berpengaruh nyata terhadap tinggi tanaman kentang. Tabel 3.2 menunjukan berbedaan rerata tinggi tanaman kentang pada pemberian pupuk hayati agrobost dengan dosis berbeda. Tanaman kentang tertinggi diperoleh pada perlakuan d2 (10 ml/L) dengan rerata tinggi yaitu $35.8 \mathrm{~cm}$ dan terendah diperoleh pada perlakuan $\mathrm{d} 4(20 \mathrm{ml} / \mathrm{L})$.

Tabel 2. Tinggi tanaman kentang dengan berbagai dosis pupuk hayati agrobost

\begin{tabular}{ccccccc}
\hline Perlakuan & \multicolumn{3}{c}{ Ulangan } & \multicolumn{2}{c}{$\begin{array}{c}\text { Rerata } \\
\text { (cm) }\end{array}$} & Deviasi \\
\cline { 2 - 5 } d0 (kontrol) & 1 & 2 & 3 & 4 & & \\
d1 (5 $\mathbf{~ m l})$ & 30.90 & 28.33 & 30.33 & 27.83 & $29.35^{\mathrm{a}}$ & 1.50 \\
$\mathbf{d 2}(\mathbf{1 0} \mathbf{~ m l})$ & 38.70 & 34.50 & 38.50 & 31.66 & $35.84^{\mathrm{a}}$ & 3.39 \\
$\mathbf{d 3}(\mathbf{1 5} \mathbf{~ m l})$ & 27.30 & 22.66 & 27.34 & 21.34 & $24.66^{\mathrm{a}}$ & 3.12 \\
$\mathbf{d 4}(\mathbf{2 0} \mathbf{~ m l})$ & 24.80 & 16.83 & 24.67 & 17.00 & $20.83^{\mathrm{a}}$ & 4.52 \\
$\mathbf{d 5}(\mathbf{2 5} \mathbf{~} \mathbf{l})$ & 26.00 & 15.17 & 35.17 & 24.03 & $25.09^{\mathrm{a}}$ & 8.20 \\
\hline
\end{tabular}

Keterangan : Angka yag diikuti huruf yang sama pada kolom berbeda menunjukan tidak berbeda nyata

\section{Jumlah daun}

Berdasarkan hasil analysis of variance (ANOVA) pemberian pupuk hayati agrobost tidak berpengaruh nyata terhadap jumlah daun tanaman kentang. Tabel 3.3 menunjukan berbedaan rerata jumlah daun tanaman kentang pada pemberian pupuk hayati agrobost dengan dosis berbeda. Tanaman kentang dengan jumlah daun terbanyak diperoleh pada perlakuan d2 (10 ml/L) dengan rerata jumlah daun yaitu 29.17 dan terendah diperoleh pada perlakuan d0 (kontrol).

Tabel 3. Rerata Jumlah daun tanaman kentang dengan berbagai dosis pupuk hayati agrobost

\begin{tabular}{|c|c|c|c|c|c|c|}
\hline \multirow[t]{2}{*}{ Perlakuan } & \multicolumn{4}{|c|}{ Ulangan } & \multirow{2}{*}{$\begin{array}{l}\text { Rerata } \\
\text { (helai) }\end{array}$} & \multirow[t]{2}{*}{ Deviasi } \\
\hline & 1 & 2 & 3 & 4 & & \\
\hline d0 (kontrol) & 16.89 & 36.11 & 5.89 & 19.78 & $19.67^{\mathrm{a}}$ & 12.49 \\
\hline d1 (5 ml) & 33.45 & 29.11 & 26.11 & 27.67 & $29.08^{\mathrm{a}}$ & 3.16 \\
\hline d2 (10 ml) & 26.11 & 29.22 & 36.56 & 24.78 & $29.17^{\mathrm{a}}$ & 5.27 \\
\hline
\end{tabular}


Procedia of Engineering and Life Science Vol. 2 No. 1 October 2021

Seminar Nasional \& Call Paper Fakultas Sains dan Teknologi (SENASAINS 3rd)

Universitas Muhammadiyah Sidoarjo

\begin{tabular}{rrrrrrr}
\hline $\mathbf{d 3}(\mathbf{1 5} \mathbf{~ m l})$ & 23.22 & 23.67 & 35.11 & 19.89 & $25.47^{\text {a }}$ & 6.64 \\
$\mathbf{d 4}(\mathbf{2 0} \mathbf{~ m l})$ & 28.44 & 19 & 38.78 & 17.78 & $26^{\text {a }}$ & 9.76 \\
$\mathbf{d 5}(\mathbf{2 5} \mathbf{~ m l})$ & 20.22 & 21.72 & 36.55 & 11.78 & $22.57^{\text {a }}$ & 10.3 \\
\hline
\end{tabular}

Keterangan : Angka yag diikuti huruf yang sama pada kolom berbeda menunjukan tidak berbeda nyata

\section{Berangkasan tanaman}

Berangkasan tanaman meliputi bagian tanaman yaitu akar, batang dan daun yang tidak ikut dipanen. Berangkasan yang diukur meliputi bobot berangkasan segar dan bobot berangkasan kering tanaman. Berdasarkan hasil analysis of varianve (ANOVA) bahwa pemberian pupuk hayati Agrobost tidak berpengaruh nyata terhadap bobot segar tanaman. Bobot berangkasan segar tanaman tertinggi didapat pada perlakuan control yaitu sebesar 98.83 gram. Sedangkan nilai terendah didappat pada perlakuan d3 (15 ml) sebesar 77.17 gram

Tabel 4. Rerata bobot berangkasan segar dan bobot berangkasan kering tanaman kentang dengan berbagai dosis pupuk hayati agrobost

\begin{tabular}{ccc}
\hline Perlakuan & \multicolumn{2}{c}{ Rerata } \\
\cline { 2 - 3 } d0 (kontrol) & Bobot Segar (gram) & Bobot Kering (gram) \\
d1 $(\mathbf{5} \mathbf{~ m l})$ & $98.83^{\mathrm{a}}$ & $1.13^{\mathrm{a}}$ \\
d2 (10 $\mathbf{~ m l})$ & $93.33^{\mathrm{a}}$ & $1.20^{\mathrm{a}}$ \\
d3 (15 $\mathbf{~ m l})$ & $91.17^{\mathrm{a}}$ & $1.43^{\mathrm{a}}$ \\
d4 (20 $\mathbf{~ m l})$ & $77.17^{\mathrm{a}}$ & $1.07^{\mathrm{a}}$ \\
d5 $(\mathbf{2 5} \mathbf{~ m l})$ & $83.83^{\mathrm{a}}$ & $1.50^{\mathrm{a}}$ \\
\hline
\end{tabular}

Keterangan : Angka yag diikuti huruf yang sama pada kolom berbeda menunjukan tidak berbeda nyata

Pemberian pupuk hayati Agrobost juga tidak berpengaruh nyata terhadap bobot berangkasan kering tanaman. Bobot berangkasan kering tanaman tertinggi didapat pada perlakuan d5 (25 ml) yaitu sebesar 1.6 gram. Sedangkan nilai terendah didappat pada perlakuan d3 $(15 \mathrm{ml})$ sebesar 1.07 gram.

\section{Jumlah umbi}

Pengamatan jumlah umbi dilakukan saat hari panen atau di umur 92 HST (hari setelah tanam). Umbi dari setiap polybag dikumpulkan dan dihitung. Berdasarkan analysis of varianve (ANOVA) pemberian pupuk hayati Agrobost tidak berpengaruh nyata terhadap parameter jumlah umbi. Walaupun begitu rerata jumlah umbi terbanyak berada pada perlakuan d2 $(10 \mathrm{ml})$ yaitu sebanyak 4.16 umbi setiap polybag. Dan jumlah umbi terkecil yaitu perlakuan d0 (kontrol) yaitu sebanyak 2.58 umbi per polybag.

Tabel 5. Rerata jumlah umbi tanaman kentang dengan berbagai dosis pupuk hayati agrobost

\begin{tabular}{|c|c|c|c|c|c|c|}
\hline \multirow[t]{2}{*}{ Perlakuan } & \multicolumn{4}{|c|}{ Ulangan } & \multirow{2}{*}{$\begin{array}{l}\text { Rerata } \\
\text { (gram) }\end{array}$} & \multirow[t]{2}{*}{ Deviasi } \\
\hline & 1 & 2 & 3 & 4 & & \\
\hline d0 (kontrol) & 2.67 & 2.67 & 2.33 & 2.67 & $2.58^{\mathrm{a}}$ & 0.17 \\
\hline d1 $(5 \mathrm{ml})$ & 3.30 & 4.67 & 4.33 & 4.00 & $4.07^{\mathrm{a}}$ & 0.65 \\
\hline d2 (10 ml) & 3.30 & 4.00 & 5.33 & 4.00 & $4.16^{\mathrm{a}}$ & 0.85 \\
\hline d3 (15 ml) & 3.00 & 3.33 & 4.67 & 2.67 & $3.42^{\mathrm{a}}$ & 0.88 \\
\hline d4 $(20 \mathrm{ml})$ & 3.30 & 2.33 & 2.33 & 3.00 & $2.74^{\mathrm{a}}$ & 0.49 \\
\hline d5 (25 ml) & 2.70 & 2.33 & 6.00 & 3.00 & $3.51^{\mathrm{a}}$ & 1.68 \\
\hline
\end{tabular}

Keterangan: Angka yang diikuti huruf yang sama pada kolom berbeda menunjukan tidak berbeda nyata

Bobot umbi

Pengamatan bobot umbi dilakukan saat hari panen atau di umur 92 HST (hari setelah tanam). Umbi dari setiap polybag dikumpulkan dan ditimbang Berdasarkan analysis of variance (ANOVA) pemberian pupuk hayati Agrobost berpengaruh nyata terhadap parameter bobot umbi. Hasil uji BNJ taraf 5\% menunjukan pemberian pupuk hayati Agrobost berpengaruh nyata terhadap pada perlakuan d4 $(20 \mathrm{ml})$ dengan rerata bobot umbi terbesar yaitu sebesar 7.71 gram umbi. Dan bobot umbi terendah yaitu perlakuan d0 (kontrol) yaitu sebanyak 3.69 gram umbi. 
Procedia of Engineering and Life Science Vol. 2 No. 1 October 2021

Seminar Nasional \& Call Paper Fakultas Sains dan Teknologi (SENASAINS 3rd)

Universitas Muhammadiyah Sidoarjo

Tabel 6. Rerata bobot umbi tanaman kentang dengan berbagai dosis pupuk hayati agrobost

\begin{tabular}{|c|c|c|c|c|c|c|}
\hline \multirow[t]{2}{*}{ Perlakuan } & \multicolumn{4}{|c|}{ Ulangan } & \multirow{2}{*}{$\begin{array}{l}\text { Rerata } \\
\text { (gram) }\end{array}$} & \multirow[t]{2}{*}{ Deviasi } \\
\hline & 1 & 2 & 3 & 4 & & \\
\hline d0 (kontrol) & 4.42 & 4.08 & 1.84 & 4.41 & $3.69^{\mathrm{a}}$ & 1.24 \\
\hline d1 (5 ml) & 7.99 & 7.71 & 5.48 & 5.08 & $6.57^{\mathrm{ab}}$ & 1.50 \\
\hline d2 (10 ml) & 10.26 & 6.13 & 5.60 & 7.86 & $7.46^{\mathrm{b}}$ & 2.10 \\
\hline d3 (15 ml) & 6.41 & 6.70 & 5.14 & 5.08 & $5.83^{\mathrm{ab}}$ & 0.85 \\
\hline d4 $(20 \mathrm{ml})$ & 10.98 & 8.87 & 7.14 & 3.87 & $7.71^{\mathrm{b}}$ & 3.01 \\
\hline d5 (25 ml) & 4.47 & 7.73 & 5.89 & 5.07 & $5.79^{\mathrm{ab}}$ & 1.42 \\
\hline
\end{tabular}

Keterangan : Angka yag diikuti huruf yang tidak sama pada kolom yang sama menunjukan berbeda nyata

\section{Pembahasan}

Karakteristik media tanam yang digunakan memiliki tekstur lempung berdebu dengan persentase pasir $4 \%$, liat $22 \%$, dan debu $74 \%$. Tanah yang bertekstur liat dan debu memiliki kemampuan menahan air dan menyediakan unsur hara yang tinggi karena butirnya berukuran kecil dan halus, serta luas permukaan lebih besar tanah tersebut cocok untuk ditanami tanaman kentang [14]. Tanah andosol merupakan jenis tanah yang paling baik untuk pertumbuhan kentang karena jenis tanah ini bertekstur debu atau lempung berdebu sampai lempung dan berstruktur remah, memiliki kandungan unsur hara sedang hingga tinggi [6].

Nilai keasaman $(\mathrm{pH})$ media tanam sebesar 6.8 tergolong netral. Pada $\mathrm{pH}$ tersebut tanaman kentang masih bisa tumbuh dengan baik tanaman kentang memiliki toleran $\mathrm{pH}$ yang cukup luas yaitu dengan selang nilai antara 4.5 sampai 8.0 namun memiliki pH optimum untuk produksi yaitu antara 5.5 hingga 6.5. Berdasarkan pengamatan yang telah dilakukan, suhu di Screen house A 07 pada bulan April sampai Juni 2021 yaitu berkisar antara $20-31^{\circ} \mathrm{C}$ dengan suhu rata-rata harian yaitu $25^{\circ} \mathrm{C}$. Tanaman kentang masih bisa tumbuh dengan baik pada suhu tersebut.

Kelembaban udara pada bulan April sampai Juni 2021 yaitu berkisar antara $61 \%$ - $99 \%$ dengan rata- rata kelembaban udara harian yaitu $81.2 \%$. Kelembaban tersebut memungkinkan tanaman kentang untuk tumbuh dengan baik karena kelembaban udara yang dibutuhkan oleh tanaman kentang yaitu sebanyak 80 - $90 \%$ [6].

Pupuk hayati Agrobost merupakan inokulan yang berbahan aktif organisme hidup yang memiliki peran untuk membantu tanaman dalam penyerapan unsur hara dalam tanah. Selain mengandung mikroorganisme, pupuk hayati Agrobost juga mengandung unsur hara diantaranya yaitu Fosfor, Kalium, C organik, besi, mangan, tembaga dan zink serta hormon pertumbuhan dan enzim. Mikroorganisme dalam pupuk hayati Agrobost akan membantu tanaman dalam menyerap unsur hara dengan mengubah dan menambat unsur hara tersebut menjadi bentuk yang sederhana sehingga lebih mudah untuk diserap. Karena unsur hara yang tersedia di dalam tanah lebih lama dan sukar terserap oleh tanaman. Agar dapat menyokong pertumbuhkembangan tanaman mikroorganisme membutuhkan unsur hara. Mikroorganisme membutuhkan karbon dan nitrogen untuk aktivitas hidupnya.

Berdasarkan uji ANOVA bahwa pemberian pupuk hayati tidak berpengaruh nyata terhadap parameter tigggi tanaman, jumlah daun, bobot berangkasan basah dan kering tanaman, serta jumlah umbi, hal ini diduga kerja mikroorganisme dalam pupuk hayati saat berada didalam media tanam tidak bekerja optimal atau bahkan tidak tersedia. Mikroorganisme dalam pupuk hayati yang diaplikasikan diatas permukaan tanah belum tentu hidup dan berkembang. Mikroorganisme tersebut bisa mati ataupun dalam masa dorman (tidur) sehingga tidak dapat membantu tanaman dalam penyerapan hara. Hal ini dapat disebabkan oleh kondisi yang tidak sesuai atau tidak tersedianya makanan yang mudah dicerna [15].

Berdasarkan nilai rasio $\mathrm{C} / \mathrm{N}$ yang didapatkan pada analisia media tanam awal (tabel 1) menunjukkan nilai yang sangat tinggi sehingga pertumbuhan mikroorganisme terhambat dan tidak dapat membantu pertumbuhkembangan tanaman. Nilai $\mathrm{C} / \mathrm{N}$ merupakan tanda akan tingkat kemudahan perombakan bahan organik oleh mikroorganisme tanah. Nilai $\mathrm{C} / \mathrm{N}$ diatas 30 maka bahan organik akan sulit terdekomposisi. Jika nilai $\mathrm{C} / \mathrm{N}$ terlalu tinggi, berarti ketersediaan unsur $\mathrm{C}$ lebih besar dibandingkan ketersediaan unsur $\mathrm{N}$ akibatnya proses pertumbuhan mikroorganisme akan terhambat. Mikrorganisme membutuhkan unsur karbon sebagai sumber energi dan nitrogen untuk sinteis protein dan pembetukan sel tubuh. Karbon adalah sumber energi mikroorganisme yang akan digunakan untuk mengikat nitrogen yang digunakan pada proses pertumbuhannya. Apabila ketersediaan karbon terbatas maka mikroorganisme tidak memiliki cukup energi untuk mengikat nitrogen. Dan jika ketersediaan karbon terlampau tinggi $(\mathrm{C} / \mathrm{N}>40)$ maka jumlah nitrogen sangat terbatas sehingga menjadi faktor pembatas pertumbuhan mikroorganisme. Mikroorgansme akan kekurangan $\mathrm{N}$ untuk sintesis protein yang menyebabkan dekomposisi berjalan lambat [16].

Pertumbuhan tanaman kentang dipengaruhi oleh kandungan unsur hara yang terdapat di dalam tanah. Unsur hara utama yang dibutuhkan oleh tanaman diantaranya yaitu N, P dan K. Unsur hara NPK memiliki fungsi yang berkaitan erat dalam medukung proses fotosintesis dan fotosintat yang dihasilkan. Unsur hara tersebut akan diubah menjadi senyawa organik atau energi yang akan membantu meningkakan pertumbuhan tanaman. Oleh karena itu 
unsur hara N, P dan K tidak dapat digantikan dengan unsur lain [17].

Jika dilihat pada tabel 1 unsur hara yang terkandung dalam media tanam sangat tinggi. Tingginya unsur hara disebabkan oleh media tanam yang digunakan dimana kandungan dari pupuk kandang ayam mengandung hara yang baik dan ditambah cocopeat yang menyumbangkan banyak unsur hara juga. Hal ini menyebabkan tidak adanya pengaruh nyata pemberian pupuk hayati Agrobost terhadap beberapa parameter pengamatan. Tanaman telah mendapat unsur hara yang cukup dan tersedia dari media tanam sehingga efektivitas penggunaan pupuk hayati kurang terlihat. Penggunaan larutan nutrisi dari pupuk anorganik yang telah tersedia dan mudah terserap oleh tanaman menyebabkan kerja pupuk hayati tidak terlihat [18].

Mekanisme pelarutan fosfat dalam media organik berkaitan dengan aktivitas mikroba dalam menghasikan enzim fosfatase. Enzim fosfatase ini berperan dalam mengubah P organik menjadi P anorganik yangmana bentuk tersebut lebih mudah diserap tanaman. Enzim fosfatase ini akan dihasilkan saat kandungan fosfat rendah. Pada penelitian ini ketersediaan fosfat sangat tinggi sehingga kinerja mikroba untuk menghasilkan enzim fotfatase kurang maksimal [19].

Pupuk hayati agrobost tidak berpengaruh nyata terhadap tinggi tanaman, jumlah daun, bobot berangkasan segar dan kering tanaman serta jumlah umbi. Nilai bobot berangkasan segar dan kering tanaman berbanding lurus dengan jumlah daun dan tinggi tanaman. Fotosintat yang dihasilkan tumbuhan akan membentuk organ tanaman seperti daun dan batang dan akan sejalan dengan pertambahan bobot berangkasan kering tanaman. Serta fase vegetatif yang baik akan menghasilkan fase generatif yang baik pula[20].

Umbi kentang merupakan bentuk pemanjangan dari stolon. Umbi kentang meruapakan sumber energi karena mengandung karbohidrat, lemak protein, vitamin, mineral dan air. Bobot umbi kentang bergantung pada fotosintat yang dihasilkan oleh tanaman serta kemampuan translokasi tanaman pada bagian umbi. Pada saat tanaman kentang mulai memasuki fase generatif, persaingan antara umbi dengan bagian atas tanaman mulai terhenti saat bagian tanaman atas telah mencapai pertumbuhan maksimun. Sehingga bagian atas tanaman berubah menjadi sumber untuk pertumbuhan dan perkembangan bagian umbi [21] .

Berdasarkan hasil analisis bahwa pupuk hayati agrobost berpengaruh terhadap bobot umbi. Hal ini diduga saat fase vegetatif, terjadi pembagian hasil fotosintat antara pembenukan umbi baru dengan pengisian umbi. Pada penelitian ini hasil fotosintat difokuskan pada pengisian umbi sehingga bobot umbi besar dan jumlah umbi sedikit. Pada tanaman kentang ukuran umbi berbanding terbalik dengan jumah umbi yang terbentuk [22]. Semakin banyak batang yang terbentuk maka jumlah umbi yang dihasilkan semakin banyak dengan ukuran umbi yang kecil. Jumlah umbi yang banyak memiliki konsekuansi yaitu ukuran umbi yang kecil [23]. Pada saat pengisian umbi fotosintat akan terbagi karena banyaknya stolon atau calon umbi batang yang terbentuk [22].

\section{KESIMPULAN}

Berdasarkan hasil penelitian yang telah dilakukan didapatkan kesimpulan bahwa pemberian pupuk hayati Agrobost berpengaruh nyata terhadap bobot umbi kentang tetapi tidak perpengaruh nyata terhadap tinggi tanaman, jumlah daun, bobot segar dan bobot kering tanaman serta jumlah umbi kentang. Pupuk hayati Agrobost dengan dosis $20 \mathrm{ml} / \mathrm{L}$ menghasilkan rerata bobot umbi tertingi yaitu seberat 7.71 gram.

\section{REFERENSI}

[1] Samadi, Usaha Tani Kentang. Yogyakarta: Kanisius, 1997.

[2] Badan Pusat Statistik, "Produksi Kentang Menurut Provinsi 2016-2017," 2017.

[3] Hadisoeganda, "Distribusi, Identifikasi, dan Prevalensi Nematoda Sista Emas, Globodera rostochiensis Wollenweber di Daerah Sentra Produksi Kentang di Indonesia," J.Hort, vol. 12, no. 1, pp. 7-12, 2006.

[4] Fatchulloh, "Uji Efektivitas Pupuk Hayati Unggulan pada Tanaman Kentang," in Semiinar Nasional Pangan, Energi dan Lingkungan, 2015, pp. 233-239.

[5] Samadi, Kentang dan Analisis Usaha Tani. Yogyakarta: Kanisius, 2007.

[6] R. Rukmana, Usaha Tani Kentang Sistem Mulsa Plastik. Yogyakarta: Kanisius, 2002.

[7] Mainnanur, R. Hayati, and Nurhayati, "Pengujian Pupuk Hayati Agrobost dan Pemangkasan Terhadap Pertumbuhan dan Hasil Tanaman Tomat (Lycopersicum esculentum Mill.)," J. Ilm. Mhs. Pertan., vol. 4, no. 1, pp. 66-72, 2019.

[8] M. Harun, "Pengaruh Penggunaan Media Tanam dan Pupuk Organik Terhadap Pertumbuhan dan Hasil Cabai Rawit (Capsicum frutescens L.)," Universitas Samudra, 2018.

[9] R. Harris, E. Kantikowati, and Wisal Hari Agustian, "Karakteristik Pertumbuhan dan Hasik Pakchoy ( Brasica rappa L.) Akibat Pemberian Pupuk Hayati Growth Characteristics and Yield of Pakchoy Plants ( Brassica rappa L.) Akibat Pemberian Pupuk Hayati,” J. AgroTatanen., vol. 1, no. 1, pp. 1-8, 2018.

[10] Direktorat Jenderal Hortikultura, Teknis Perbanyakan Dan Sertifikasi Benih Kentang. Kementrian Pertanian Direktorat Jenderal Hortikultura Direktorat Perbenihan Hortikultura, 2014.

[11] D. Lestari, "Pengaruh Pupuk Organik Cair (POC) Terhadap Pertumbuhan dan Produksi Jagung Zea mays L. Lokal Bebo dan Kandora Asal Tana Toraja Sulawesi Selatan,” Universitas Hasanudin Makassar, 2018. 
Procedia of Engineering and Life Science Vol. 2 No. 1 October 2021

Seminar Nasional \& Call Paper Fakultas Sains dan Teknologi (SENASAINS 3rd)

Universitas Muhammadiyah Sidoarjo

[12] R. Hairuddin and R. Mawardi, "Efektivitas Pupuk Organik Air Cucian Beras Terhadap Pertumbuhan Tanaman Sawi Hijau (Brassica juncea L)," J. Perbal, vol. 3, no. 3, pp. 1-8, 2015.

[13] A. Hilman, "PENGARUH BENIH PENJENIS KENTANG ( Solanum tuberosum L .) DAN MEDIA TANAM TERHADAP PERTUMBUHAN DAN HASIL BENIH DASAR DENGAN TEKNIK HIDROPONIK SUBSTRAT," UIN Sunan Gunung Djati, 2020.

[14] E. J. Gurning, "Karakteristik Sifat Kimia Tanah pada Tutupan Lahan di Kecamatan Sei Bingai Kabupaten Langkat," Universitas Sumatera Utara, 2018.

[15] Missdiani, Lusmaniar, and P. Hariani, "Pengaruh Komposisi Media Tanam dan Konsentrasi Pupuk Hayati Agrobost Terhadap Pertumbuhan dan Produksitanaman Sawi Hijau (Brassica juncea L.) dalam Polybag," Ilmu Pertan. Agronitas, vol. 2, no. 1, pp. 17-30, 2020.

[16] A. . Wallace, Hand Book Of Soil Conditoner Subsistance Than Enhance The Physical Properties Of Soil. New York: Marcell Parker, Inc, 2000.

[17] I. Anggraeni, "Pemberian Pupuk Organik Cair dan Pupuk Organik Padat Terhadap Pertumbuhan Tanaman Sawi (Branssica juncea)," Universitas Islam Negeri Raden Intan Lampung, 2018.

[18] W. Astari, K. I. Purwani, and W. Anugerahani, "Pengaruh Aplikasi Pupuk Hayati Terhadap Pertumbuhan dan Produktifitas Tanaman Tomat (Solanum lycopersicum L).," J. Sains dan Seni Pomits Pomit, vol. 2, no. 1, 2014.

[19] A. Rana, M. R. Setiawati, and A. Suriadikusumah, "Pengaruh Pupuk Hayati Dan Anorganik Terhadap Populasi Bakteri Pelarut Fosfat, Kandungan FOsfat (P), dan Hasil Tomat Hidroponik," J. Biodjati, vol. 3, no. 1, pp. 1522, 2018.

[20] Wagino, S. M. Tarigan, and E. B. Febrianto, "Respon Pertumbuhan Kelapa Sawit (Elaeis GuineensisJacq.) Varietas Dyxp Dumpy pada Kondisi Stres Air di Pembibitan Awal,” J. Agroteknologi dan Ilmu Pertan., vol. 3, no. 1, pp. 17-26, 2018.

[21] P. Hidayah, M. Izzati, and S. Parman, "Pertumbuhan dan Produksi Tanaman Kentang (Solanum tuberosum L. var. Granola) pada Sistem Budidaya yang Berbeda," Bul. Anat. dan Fisiol., vol. 2, no. 2, p. 218, 2017, doi: 10.14710/baf.2.2.2017.218-225.

[22] U. G. Fathiyah, M. Izzati, and S. Haryanti, "PENGARUH BERAT MEDIA DAN JUMLAH BIBIT TERHADAP PERTUMBUHAN DAN PRODUKSI KENTANG (Solanum tuberosum L.) DI DALAM POLYBAG," J. Biol., vol. 6, no. 4, 2017.

[23] D. Fatchullah, "Pengaruh Variasi Jarak Tanam Dan Berat Umbi Generasi NOL ( G0 ) ( Solanum tuberosum L .) Generasi Dua ( G2 ) Varietas Granola,” Pros. Semin. Nas. III, pp. 55-64, 2017. 